\title{
Large grazers modify effects of aboveground-belowground interactions on small-scale plant community composition
}

\author{
G. F. (Ciska) Veen · Elzemiek Geuverink • \\ Han Olff
}

Received: 10 November 2010/Accepted: 19 July 2011/Published online: 24 August 2011

(C) The Author(s) 2011. This article is published with open access at Springerlink.com

\begin{abstract}
Aboveground and belowground organisms influence plant community composition by local interactions, and their scale of impact may vary from millimeters belowground to kilometers aboveground. However, it still poorly understood how large grazers that select their forage on large spatial scales interact with small-scale aboveground-belowground interactions on plant community heterogeneity. Here, we investigate how cattle (Bos taurus) modify the effects of interactions between yellow meadow ants (Lasius flavus) and European brown hares (Lepus europaeus) on the formation of small-scale heterogeneity in vegetation composition. In the absence of cattle, hares selectively foraged on ant mounds, while under combined grazing by hares and cattle, vertebrate grazing pressure was similar on and off mounds. Ant mounds that were grazed by only hares had a different plant community composition compared to their surroundings: the cover of the grazingintolerant grass Elytrigia atherica was reduced on ant mounds, whereas the relative cover of the more grazingtolerant and palatable grass Festuca rubra was enhanced. Combined grazing by hares and cattle, resulted in homogenization of plant community composition on and off ant mounds, with high overall cover of $F$. rubra. We
\end{abstract}

Communicated by Bernhard Schmid.

G. F. Veen $(\bowtie)$ E. Geuverink · H. Olff

Community and Conservation Ecology Group,

University of Groningen, PO Box 11103 ,

9700 CC Groningen, The Netherlands

e-mail: ciska.veen@gmail.com

G. F. Veen

Department of Terrestrial Ecology,

Netherlands Institute of Ecology (NIOO-KNAW),

Droevendaalsesteeg 10, 6708 PB Wageningen, The Netherlands conclude that hares can respond to local ant-soil-vegetation interactions, because they are small, selective herbivores that make their foraging decisions on a local scale. This results in small-scale plant patches on mounds of yellow meadow ants. In the presence of cattle, which are less selective aboveground herbivores, local plant community patterns triggered by small-scale abovegroundbelowground interactions can disappear. Therefore, cattle modify the consequences of aboveground-belowground interactions for small-scale plant community composition.

Keywords Plant-herbivore interactions · Plant community heterogeneity - Herbivore selectivity . Elytrigia atherica $\cdot$ Festuca rubra

\section{Introduction}

It is widely acknowledged that aboveground and belowground communities interact, using plants as intermediates (Wardle et al. 2004). However, while many studies have shown that aboveground or belowground organisms may influence the spatial and temporal composition of plant communities (e.g., Milchunas and Lauenroth 1993; Dobson and Crawley 1994; Olff and Ritchie 1998; van der Heijden et al. 1998; Olff et al. 2000; Bradford et al. 2002; Klironomos 2002; De Deyn et al. 2003), relatively few studies have examined their combined effects in a community context. Most previous research on aboveground-belowground interactions has focused on single plant species with specific aboveground and belowground organisms affecting the plant and each other (e.g., Gange and Brown 1989; Masters and Brown 1992; Masters 1995; Gange and Nice 1997; Soler et al. 2005, 2007). However, in natural situations, these interactions occur in diverse communities. 
The available studies that did investigate abovegroundbelowground interactions in diverse plant communities showed that the interactive aboveground-belowground effects on plant community structure are not always simply additive (Brown and Gange 1992; Blomqvist et al. 2000; van Ruijven et al. 2005). Hence, the potential of belowground organisms to drive small-scale plant patterns will be dependent on the activities of aboveground organisms.

An important aspect of combined aboveground-belowground effects in natural communities is the huge difference in spatial scale at which most soil biota affect plants compared to some aboveground organisms, such as vertebrate grazers, due to limited mobility belowground and fewer restrictions aboveground (Mortimer et al. 1999; van der Putten et al. 2009). However, it is not yet clear to what extent aboveground herbivores that operate at very different spatial scales than soil organisms influence the outcome of aboveground-belowground interactions in a community context. Here, we investigate how vertebrate herbivores that operate across large spatial scales alter the effects of small-scale aboveground-belowground interactions on plant community composition. In a field experiment on the island of Schiermonnikoog (the Netherlands), we studied plant community patches on mounds of subterranean yellow meadow ants (Lasius flavus) in the presence of small vertebrate herbivores (European brown hares, Lepus europaeus) and in the presence of both small (European brown hares) and large (cattle, Bos taurus) vertebrate herbivores.

Hares are relatively small vertebrate herbivores, while cattle are much larger. The body size of vertebrate herbivores is generally associated with their foraging selectivity, and hence with the scale at which they perceive and select food patches. Smaller herbivore species require a higher quality diet and more energy per unit body mass than large herbivores, which have a longer residence time of food in their digestive system (Demment and Van Soest 1985; Gordon and Illius 1994). Therefore, small herbivores are forced to choose their forage selectively, while large herbivores can be less selective in their diet selection (Olff et al. 2002; Hopcraft et al. 2010). As a result, large herbivores are expected to have larger home ranges (Haskell et al. 2002) and neglect detail in their environment when foraging (Ritchie and Olff 1999). Consequently, effects of small, selective herbivores on vegetation composition are more localized, specific and small scale, while effects of larger, less selective herbivores are often more generic, less specific and large scale (Ritchie and Olff 1999; Haskell et al. 2002; Cromsigt and Olff 2006; Mouissie et al. 2008; Laca et al. 2010).

Yellow meadow ants are subterranean social insects that locally alter abiotic and biotic soil properties by digging up fresh soil to build nest mounds (Dean et al. 1997;
Blomqvist et al. 2000; Dauber and Wolters 2000; Dostal et al. 2005) of 0.1-1 $\mathrm{m}$ in diameter, up to $0.5 \mathrm{~m}$ tall. They tend root aphids in their nest for honey dew exploitation (Pontin 1978). These changes in soil properties result under some conditions in a different plant community composition on and off yellow meadow ant mounds and hence in small-scale plant community patches (e.g., Dean et al. 1997; Blomqvist et al. 2000).

Aboveground vertebrate herbivores may respond to plant community changes induced by yellow meadow ants. The foraging selectivity of aboveground herbivores will determine how they interact with local plant patches on ant mounds. Hares may respond to small-scale plant community changes on ant mounds, whereas cattle may not be able to select for them in particular. This can affect plant community heterogeneity at the local scale (Olff et al. 1999; Bakker 2003; Cromsigt and Olff 2008). Therefore, we hypothesized that the interaction between ants, hares and cattle can drive small-scale plant community heterogeneity. We expect that interactions between ants and hares will result in more heterogeneous plant community composition at the local scale. In contrast, plant community patches are expected to be more homogeneous when aboveground vertebrates such as cattle that forage on a coarser grain are present as well.

\section{Materials and methods}

\section{Site description}

Our study was conducted at the salt marsh of Schiermonnikoog, a barrier island in the Dutch Wadden Sea $\left(53^{\circ} 30^{\prime} \mathrm{N}, 6^{\circ} 10^{\prime} \mathrm{E}\right)$. The salt marsh consists of two parts. One part is grazed by cattle (approx. 400 ha) from May to October at stocking rates of about1.0 animal/ha and the other part is not grazed by cattle (approx. 1,800 ha). The cattle-grazed part was not grazed by cattle between 1958 and 1989. The part without cattle was grazed by cattle before 1958 but they have been excluded ever since. Natural vertebrate herbivores grazing the salt marsh are brown hares and rabbits. They are present in both the part that is grazed by cattle and the part that is not grazed by cattle. In our research area, rabbits have been reduced to permanently low densities since the outbreak of the Rabbit Hemorrhagic Disease (RHD) in the early 1990s. Therefore, we will refer to the salt marsh grazed by cattle as cattle+hare-grazed marsh and to the cattle-excluded salt marsh as hare-grazed marsh.

In the absence of cattle, the salt marsh is dominated by the grass Elytrigia atherica (Sea couch), while the cattle+hare-grazed marsh has a more diverse plant community with the grass Festuca rubra (Red fescue) as one of the 
dominant plant species. Yellow meadow ants (Lasius fla$v u s$ ) are abundant subterranean invertebrates in the salt marsh. Although the occupation of nest mounds is dynamic (i.e., about $2 / 3$ of the nest mounds is abandoned or colonized by other ant species after a decade), the mounds themselves are stable structures constructed of soil that remain present in the landscape for many decades (Waloff and Blackith 1962). Therefore, yellow meadow ants can have long-lasting effects on local plant community composition.

\section{Experimental setup and data collection}

In the fall of 2006, we randomly located five blocks of $20 \mathrm{~m} \times 20 \mathrm{~m}$ along the cattle fence line on the salt marsh such that half of each block was located in the site grazed by cattle and hares and half was in the site grazed exclusively by hares. Elevation, and hence sea flooding frequency, within each block was similar. In each grazing treatment within a block, we randomly selected 4 Lasius flavus mounds. We set up paired plots of $50 \mathrm{~cm} \times 50 \mathrm{~cm}$, where one of the plots was situated on top of a mound, and the other $1 \mathrm{~m}$ from that mound. In each of the plots, we recorded vegetation composition by visually estimating cover of the plant species. In total, we used 4 treatments: (1) ants absent and hares present, (2) ants present and hares present, (3) ants absent and hares and cattle present, and (4) ants present and hares and cattle present. Each treatment was replicated 20 times (5 blocks per grazing treatments $\times 4$ paired plots).

In the summer of 2007, we selected ant mounds and paired control plots in hare- $(n=25$ pairs $)$ and cattle+hare-grazed ( $n=25$ pairs) salt marsh to perform more detailed measurements on the mounds and the plant community. Plots were located at the same study location as in 2006. In each plot, we measured the height of the vegetation on and off ant mounds by recording the settling height of a Styrofoam disc (20 cm diameter, $70 \mathrm{~g}$ weight) that was dropped on top of the vegetation (e.g., Bransby et al. 1977; Sharrow 1984). Moreover, to determine the size of the ant mounds, we measured the height and diameter. Finally, in each plot, we laid out a transect of $1 \mathrm{~m} \times 0.1 \mathrm{~m}$, which consisted of 10 subplots of $0.1 \mathrm{~m} \times 0.1 \mathrm{~m}$ to assess vertebrate grazing frequency on the dominant plant species. In 2007, we measured grazing frequency of vertebrate herbivores. In all subplots of the paired transects (see experimental setup), we randomly counted 10 tillers (or all tillers when there were less than 10) of E. atherica and F. rubra and recorded how many of those were grazed. Moreover, we recorded the number of hare droppings present in each $0.1 \mathrm{~m} \times 0.1 \mathrm{~m}$ subplot, which is regarded a good measure for hare grazing pressure within a specific habitat (Langbein et al. 1999).
Additionally, at the end of the summer of 2009, we collected green plant biomass of E. atherica and F. rubra to determine nutrient content in plant tissue. Samples were collected on 6 mounds and in 6 paired control plots in haregrazed salt marsh. Plots were situated at the same study location as used in 2006 and 2007. Paired control plots were situated $1 \mathrm{~m}$ from mounds. Plant samples were dried $\left(70^{\circ} \mathrm{C}\right.$ for $24 \mathrm{~h}$ ) and ground, and than analyzed for $\mathrm{C}$ and $\mathrm{N}$ content with an autoanalyzer (EA 1110; Interscience, New York, USA).

We acknowledge that it would have been ideal to measure all variables within 1 year in the same plots; however, our plots were non-permanent and, based on our findings, we gradually developed ideas for measuring additional useful parameters. Moreover, we are aware that our current experiment was lacking a treatment without vertebrate herbivores, because long-term hare exclosures were not available near to our study plots. Therefore, we cannot control for ant mound effects on the plant community in the absence of aboveground vertebrate herbivores. However, previous work on Schiermonnikoog indicated that exclusion of all aboveground vertebrate grazers (i.e., cattle and hares) resulted in a homogeneous stand of E. atherica (Olff et al. 1997; Bos et al. 2002; Kuijper et al. 2004; Kuijper and Bakker 2005).

\section{Data analysis}

In our experiment, E. atherica, F. rubra and bare soil represented the most dominant groups with their cover percentages adding up to $82 \%$ (cattle+hare-grazed, off mound), $93 \%$ (cattle+hare-grazed, on mound), 102\% (hare-grazed, off mound) and $89 \%$ (hare-grazed, on mound) in the four treatments. Therefore, we focus data analysis of the plant community on just the dominant plant species $E$. atherica and $F$. rubra.

We analyzed the cover values of the dominant plant species and the number of hare droppings with a generalized linear mixed model assuming a Poisson error distribution and log-link function, because data were counts. Grazing frequency was analyzed with a logistic regression with a logit link function, because tillers counted were either grazed or ungrazed (i.e., binomial). Plant quality, expressed as percentage $\mathrm{N}$ measured in leaves and as $\mathrm{C} / \mathrm{N}$ ratio, and ant mound height and diameter were analyzed using a general linear mixed model. Data on ant mound height were log-transformed to improve normality (Shapiro test) and homogeneity of variances (Levene's test). In all analyses, grazing treatment and ant mound presence were used as fixed factors and the experimental setup was described by a random factor. For plant community data collected in the random block design in 2006, the random factor was described by nesting paired plot in grazing 


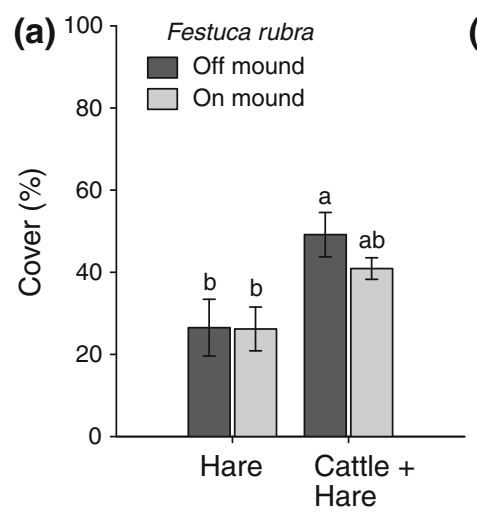

Fig. 1 Percentage cover of the plant species in the plots on and off ant mounds in hare-grazed and cattle+hare-grazed salt marsh (mean $\pm \mathrm{SE}, n=20$ ): a Festuca rubra, b Elytrigia atherica and

treatment in block, i.e., block/grazing treatments/paired plot. For data on grazing frequency collected in the subplots of the transects on mounds and controls (2007), the random factor was described by nesting subplot within paired plot within grazing treatment, i.e., grazing treatment/paired plot/subplot. For the other analyses, we only used paired plot nested within grazing treatment as a random factor, i.e., grazing treatment/paired plot.

All data were analyzed using $\mathrm{R}$, version 2.10.0. The lme4 package (Bates and Maechler 2009) was used to calculate general and generalized linear mixed models and logistic regression, using maximum likelihood estimation. To determine effects of our fixed factors, we used a likelihood ratio test to compare models with and without the variable of interest (Crawley 2007) using a chi-square test statistic. When interaction effects were significant, we do not report the effects of the main factors (Crawley 2007). Post hoc comparisons were made by pairwise comparisons between all treatments in a non-parametric Mann-Whitney $U$ test.

\section{Results}

Plant community responses

F. rubra cover was increased in the cattle+hare-grazed salt marsh in general, with a maximum cover off ant mounds under cattle grazing $\left(\chi^{2}=4.92, d f=1, \quad P=0.026\right.$; Fig. 1a). An interaction between the presence of yellow meadow ants and grazing treatment affected the cover of E. atherica and the relative cover of F. rubra. E. atherica cover was higher off ant mounds in hare-grazed salt marsh only $\left(\chi^{2}=184.61, d f=1, P<0.001\right.$; Fig. 1 b). The relative cover of $F$. rubra [cover $F$. rubra/(cover $F$. rubra + E. atherica)] was significantly lower off ant mounds in haregrazed salt marsh only $\left(\chi^{2}=131.43, d f=1, P<0.001\right.$;

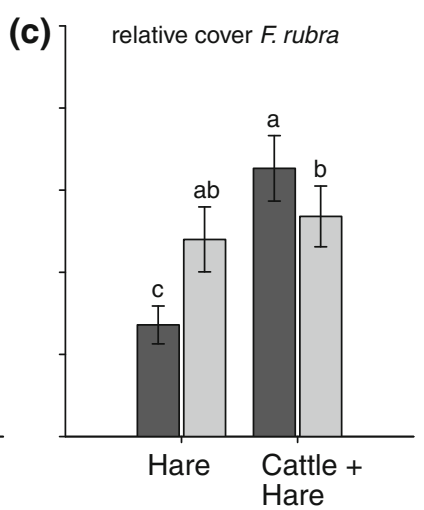

c relative percentage cover of $F$. Rubra. Different letters above the bars indicate significant differences at $P<0.05$ (pairwise comparisons with a non-parametric Mann-Whitney $U$ test)

Fig. 1c), indicating a shift in plant dominance from F. rubra to E. atherica off ant mounds under hare grazing. In contrast, in cattle+hare-grazed salt marsh both on ant mounds and in their surroundings, F. rubra was relatively dominant with a slightly higher relative cover off mounds as compared to on mounds.

Vegetation height was affected by an interaction between grazing treatment and mound presence $\left(\chi^{2}=31.41, P<0.001, d f=1\right)$. Vegetation was higher off mounds in hare-grazed marsh, while there was no difference between vegetation height on hare-grazed mounds and on and off cattle+hare-grazed mounds. This indicates that only plots off mounds in hare-grazed salt marsh developed tall vegetation and were probably grazed less often than all other plots.

Plant quality on ant mounds in hare-grazed salt marsh was enhanced. For F. rubra, percentage of nitrogen in leaf tissue was higher on ant mounds (on mounds $2.20 \pm 0.08$; off mounds $1.57 \pm 0.01 ; \chi^{2}=8.67, d f=1, P=0.003$ ) and $\mathrm{C} / \mathrm{N}$ ratio was reduced (on mounds $20.4 \pm 1.83$; off mounds $\left.26.8 \pm 0.68 ; \chi^{2}=8.88, d f=1, P=0.003\right)$. For E. atherica, percentage of nitrogen also tended to be increased in leaf tissue on ant mounds (on mounds $1.38 \pm 0.03$; off mounds $1.19 \pm 0.03 ; \chi^{2}=3.61, d f=1$, $P=0.057$ ) and $\mathrm{C} / \mathrm{N}$ ratio tended to be lower (on mounds $8.8 \pm 1.41 ;$ off mounds $28.9 \pm 1.24 ; \chi^{2}=3.23, d f=1$, $P=0.072)$.

\section{Grazing frequency}

Grazing frequency on $F$. rubra was lower off than on ant mounds in hare-grazed salt marsh $\left(\chi^{2}=16.59, P<0.001\right.$, $d f=1$; Fig. 2a). This shows that hares alone were exerting high grazing pressure on ant mounds in hare-grazed marsh, resembling that of cattle and hares together in cattle+haregrazed marsh (Fig. 2a). In the cattle+hare grazed salt marsh, grazing pressure of vertebrate herbivores on 

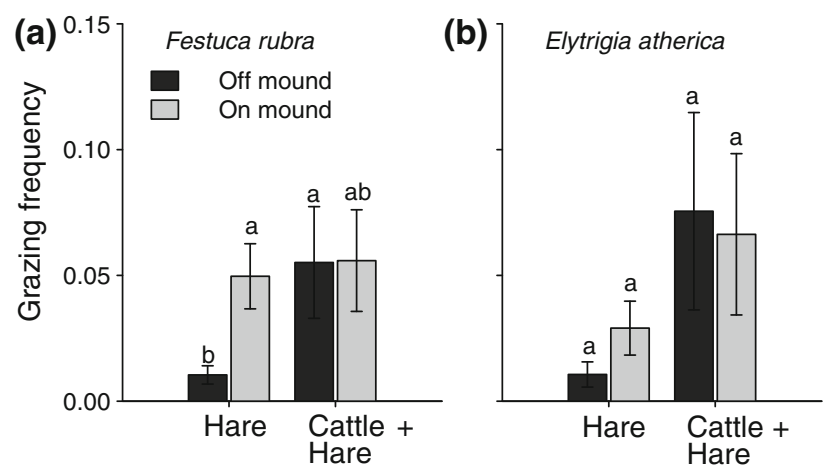

Fig. 2 Grazing frequency by vertebrate herbivores (mean $\pm \mathrm{SE}$, $n=25$ ) on and off ant mounds in hare-grazed and cattle +hare-grazed salt marsh for the two dominant plant species a F.rubra and b E. atherica. Different letters above the bars indicate significant differences at $P<0.05$ (pairwise comparisons with a non-parametric Mann-Whitney $U$ test)

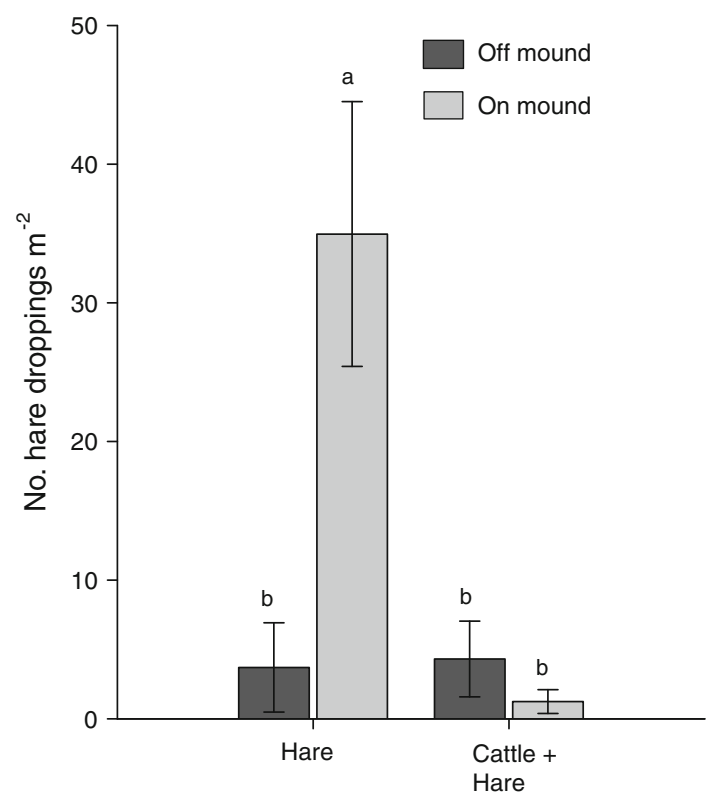

Fig. 3 Number of hare droppings (mean \pm SE, $n=25$ ) on and off ant mounds in hare-grazed and cattle+hare-grazed salt marsh. Different letters above the bars indicate significant differences at $P<0.05$ (pairwise comparisons with a non-parametric Mann-Whitney $U$ test)

F. rubra did not differ significantly on and off ant mounds. $E$. atherica tended to be grazed more frequently in cattle+hare-grazed marsh and tended to be grazed least frequent off mounds in hare-grazed salt marsh $\left(\chi^{2}=2.83\right.$, $P=0.092, d f=1$; Fig. 2b).

Counts of hare droppings revealed a similar pattern as grazing frequency data (Fig. 3). We found most hare droppings per $\mathrm{m}^{2}$ on ant mounds in hare-grazed salt marsh $\left(\chi^{2}=15.39, P<0.001, d f=1\right)$, while almost no droppings were observed both off ant mounds in the haregrazed marsh and both on and off ant mounds in the cattle+hare-grazed marsh. This indicates that hares were specifically attracted to ant mounds in the absence of cattle, while in the presence of cattle hares spend similar amounts of time on and off ant mounds.

\section{Mound characteristics}

Ant mounds had a larger diameter $(F=38.04, P<0.001$, $d f=1)$ in hare-grazed than in cattle+hare-grazed marsh, but did not differ in height $(F=2.20, P=0.141, d f=1)$.

\section{Discussion}

Subterranean yellow meadow ants are ecosystem engineers (Jones et al. 1994, 1997) that modify biotic and abiotic soil properties which can enhance small-scale plant community mosaics (Waloff and Blackith 1962; Pontin 1978; Dean et al. 1997; Olff et al. 2000; Blomqvist et al. 2000). We showed that the development of plant mosaics on ant mounds does not only depend on altered soil properties (Blomqvist et al. 2000) but also on the identity of the aboveground herbivores that are present. We found that grazing by hares alone altered plant community composition on mounds of yellow meadow ants, while grazing by cattle and hares in combination resulted in more similar plant community composition on and off ant mounds. In the presence of hares, the cover of the grass E. atherica decreased. Although the absolute cover of F. rubra was not increased on ant mounds, it did become the most dominant living plant on the ant mounds under hare grazing (i.e., the relative cover increased). When both hares and cattle were present, ant mounds and their surroundings were dominated by $F$. rubra, and plant cover on and off mounds was relatively similar. Therefore, our results show that smallscale plant community mosaics created by abovegroundbelowground interactions can be modified by aboveground grazers that select their food on large spatial scales.

The interaction between hares and ants resulted in a shift in plant community composition on ant mounds. We found that hares were grazing more intensively on mound vegetation. On the one hand, ants speed up local mineralization rates through higher soil aeration (Blomqvist et al. 2000) and fragmentation of soil organic matter, which can lead to an enhanced nitrogen content in plants growing on mounds. Hares may have been attracted specifically to high-quality plants on mounds of yellow meadow ants. On the other hand, hares could have been using ant mounds for other reasons than enhanced food quality, for example as lookout points, thereby simultaneously increasing grazing pressure on mound vegetation. Herbivore grazing has been found to speed up nutrient cycling, which improves the quality of plants and hence results in the attraction of more herbivores 
(McNaughton 1984; Bardgett and Wardle 2003). Thus, increased hare grazing itself may have resulted in increased plant nutrient content and higher hare grazing pressure on ant mounds.

In our study, we could not distinguish whether ants improved plant nutrient content via changes in biotic and abiotic soil conditions or whether this was the result of a positive feedback loop induced by herbivore grazing itself. Yet, regardless of the mechanisms, we expect that, once hares have been grazing on the ant mounds, they further increase the quality of their own food. Increased grazing pressure of hares on ant mounds locally reduced the dominance of the grazing-intolerant and unpalatable plant species $E$. atherica and enhanced the relative cover of F. rubra, a grazing-tolerant plant species of higher nutritional value (Kuijper et al. 2004). Absolute cover values of $F$. rubra on and off mounds did not change, but $F$. rubra became the most dominant living plant on the mounds due to the decrease of E. atherica. An increase in the relative cover of $F$. rubra results in easier access for hares to this plant species, because it grows less intermingled with unpalatable plant species like E. atherica. As $F$. rubra is a preferred food plant of hares (Kuijper et al. 2008), ant mounds will become increasingly attractive to hares. This will result in a progressive shift in community composition towards a domination of $F$. rubra.

In contrast, in cattle+hare-grazed salt marsh, plant species composition in patches on and off ant mounds was more similar. On the one hand, cattle grazing may have overruled effects of hares on the creation of small-scale plant community heterogeneity. On the other hand, large vertebrate grazers like cattle can homogeneously increase plant quality on a large scale (McNaughton 1984; Bardgett and Wardle 2003). Thereby, the need for hares to select for plant patches on ant mounds is reduced, and hence their impact on local plant species composition on ant mounds is also lower. We found that both vertebrate grazing frequency and number of hare droppings on and off ant mounds was not different in the presence of hares and cattle, showing that neither cattle nor hares particularly selected plant patches on ant mounds. This indicates that cattle reduce selective grazing by hares on ant mounds, because they probably increase the overall quality of the vegetation. Previous studies have shown that cattle reduce the cover of $E$. atherica and enhance the cover of highquality and grazing-tolerant $F$. rubra on a landscape scale (Olff et al. 1997). As a result, cattle facilitate hares by increasing food quality on a landscape scale (Kuijper et al. 2008) and therefore hares do not have to select for specific high-quality patches. This results in more homogeneous grazing pressure of vertebrates (i.e., both hares and cattle) across large spatial scales and hence to more homogeneous plant community composition on the local scale (Glenn et al. 1992; Bakker 2003). Therefore, herbivores that choose their forage on large spatial scales may modify interactive effects of soil organisms and selective herbivores on small-scale plant community composition. How strong such effects of large grazers are will probably also depend on herbivore type and herbivore density.

We showed that selective herbivores that forage on a fine grain can specifically respond to vegetation patterns created by soil organisms, while herbivores that select their food at larger scales may not respond to local changes in the plant community. This implies that, when aboveground herbivores and soil organisms affect plant patterns on a similar scale, they can influence each other's patch selection and thereby drive plant community patterns. This has also been confirmed by previous studies. For example, prairie dogs, which are digging, social, vertebrate herbivores, build colonies that can range over more than 100 ha. At these scales, the prairie dogs alter plant community composition and increase the nutritional value of the vegetation (Coppock et al. 1983a). Bison, which are large vertebrate grazers, are able to respond to such large-scale patches and have been shown to selectively forage in habitats affected by prairie dog colonies, probably due to changes in plant community structure and increased food quality (Coppock et al. 1983b). Another example showed that large herbivores responded to manipulated plant patches only above a certain threshold size. This subsequently induced the formation of large-scale grazing lawns (Cromsigt and Olff 2008). In contrast, when aboveground and belowground organisms affect plant patterns on very different scales, they may not be able to respond to each other's changes in the plant community and hence they can overrule each other's effects on plant species composition.

Our study shows that the interactions between hares and yellow meadow ants results in altered plant community composition on ant mounds. However, in the absence of all vertebrate herbivores, plant community composition may also be different on and off ant mounds, because ants modify biotic and abiotic soil properties (Jones et al. 1994, 1997; Blomqvist et al. 2000). We did not measure plant community composition in ungrazed situations in our study; however, previous research in our study area showed that the plant community developed in a homogeneous stand of E. atherica when aboveground vertebrate herbivores are absent (Olff et al. 1997; Bos et al. 2002; Kuijper et al. 2004; Kuijper and Bakker 2005). Moreover, in other sites, it has been shown that ant colonies can disappear when the vegetation becomes too tall after the cessation of grazing (King 1977). Therefore, we think that the selective grazing by hares on ant mounds was an important determinant of the changes in plant species composition, particularly because we found a strong increase in hare-grazing frequency and number of 
hare droppings on ant mounds, as compared to off mounds.

\section{Conclusions}

The interaction between subterranean yellow meadow ants and hares resulted in a shift in plant community composition on ant mounds, because hares specifically selected for plant patches on ant mounds. In contrast, in the presence of cattle, vertebrate herbivores (both hares and cattle) exerted a more homogeneous grazing pressure on and off ant mounds leading to more homogeneous vegetation composition. Therefore, cattle modified the interactive effects of ants and hares on local plant patches. We conclude that aboveground vertebrate herbivores can modify effects of aboveground-belowground interactions on plant community composition. The promotion of small-scale plant community heterogeneity as a result of abovegroundbelowground interactions is dependent on the selectivity of aboveground herbivores.

Acknowledgments We would like to thank Jan P. Bakker for his inspiration during the setting up of the field experiment. We thank Wim H. van der Putten and three anonymous reviewers for valuable comments on earlier versions of this manuscript. Thanks to all students from the University of Groningen (the Netherlands) and Oldenburg (Germany) that helped in the field. We would like to thank Jacob Hogendorf for technical assistance and Nelly Eck for laboratory analyses. Maarten Schrama collected grass samples on Schiermonnikoog. We are grateful to the "Vereniging Natuurmonumenten" for permission to do field work at the salt marsh of Schiermonnikoog. All experiments performed for this research comply with the current laws of the Netherlands.

Open Access This article is distributed under the terms of the Creative Commons Attribution Noncommercial License which permits any noncommercial use, distribution, and reproduction in any medium, provided the original author(s) and source are credited.

\section{References}

Bakker ES (2003) Herbivores as mediators of their environment, the impact of large and small species on vegetation dynamics. $\mathrm{PhD}$ thesis, University of Wageningen

Bardgett RD, Wardle DA (2003) Herbivore-mediated linkages between aboveground and belowground communities. Ecology 84:2258-2268. doi:10.1890/02-0274

Bates D, Maechler M (2009) lme4: Linear mixed-effects models using S4 classes. R package lme4, version 0.99

Blomqvist MM, Olff H, Blaauw MB, Bongers T, van der Putten WH (2000) Interactions between above- and belowground biota: importance for small-scale vegetation mosaics in a grassland ecosystem. Oikos 90:582-598. doi:10.1034/j.1600-0706.2000. 900316.x

Bos D, Bakker JP, de Vries Y, van Lieshout S (2002) Long-term vegetation changes in experimentally grazed and ungrazed back- barrier marshes in the Wadden Sea. Appl Veg Sci 5:45-54. doi: 10.1111/j.1654-109X.2002.tb00534.X

Bradford MA, Jones TH, Bardgett RD, Black HIJ, Boag B, Bonkowski M, Cook R, Eggers T, Gange AC, Grayston SJ, Kandeler E, Mccaig AE, Newington JE, Prosser JI, Setälä H, Staddon PL, Tordoff GM, Tscherko D, Lawton JH (2002) Impacts of soil faunal community composition on model grassland ecosystems. Science 298:615-618. doi:10.1126/science.1075805

Bransby DI, Matches AG, Krause GF (1977) Disk meter for rapid estimation of herbage yield in grazing trials. Agron J 69:393-396

Brown VK, Gange AC (1992) Secondary plant succession-how is it modified by insect herbivory. Vegetatio 101:3-13. doi:10.1007/ BF00031910

Coppock DL, Detling JK, Ellis JE, Dyer MI (1983a) Plant-herbivore interactions in a North-American mixed-grass prairie. 1. Effects of black-tailed prairie dogs on intraseasonal above ground plant biomass and nutrient dynamics and plant species diversity. Oecologia 56:1-9. doi:10.1007/BF00378210

Coppock DL, Ellis JE, Detling JK, Dyer MI (1983b) Plant-herbivore interactions in a North-American mixed-grass prairie. 2. Responses of bison to modification of vegetation by prairie dogs. Oecologia 56:10-15. doi:10.1007/BF00378211

Crawley MJ (2007) The R book. Wiley, Chichester

Cromsigt JPGM, Olff H (2006) Resource partitioning among savanna grazers mediated by local heterogeneity: an experimental approach. Ecology 87:1532-1541. doi:10.1890/0012-9658

Cromsigt JPGM, Olff H (2008) Dynamics of grazing lawn formation: an experimental test of the role of scale-dependent processes. Oikos 117:1444-1452. doi:10.1111/j.0030-1299. 2008.16651

Dauber J, Wolters V (2000) Microbial activity and functional diversity in the mounds of three different ant species. Soil Biol Biochem 32:93-99. doi:10.1016/S0038-0717(99)00135-2

De Deyn GB, Raaijmakers CE, Zoomer HR, Berg MP, de Ruiter PC, Verhoef HA, Bezemer TM, van der Putten WH (2003) Soil invertebrate fauna enhances grassland succession and diversity. Nature 422:711-713. doi:10.1038/nature01548

Dean WRJ, Milton SJ, Klotz S (1997) The role of ant nest-mounds in maintaining small-scale patchiness in dry grasslands in Central Germany. Biodivers Conserv 6:1293-1307. doi:10.1023/A:1018 313025896

Demment MW, Van Soest PJ (1985) A nutritional explanation for body-size patterns of ruminant and non-ruminant herbivores. Am Nat 125:641-672

Dobson A, Crawley W (1994) Pathogens and the structure of plantcommunities. Trends Ecol Evol 9:393-398. doi:10.1016/01695347(94)90062-0

Dostal P, Breznova M, Kozlickova V, Herben T, Kovar P (2005) Antinduced soil modification and its effect on plant below-ground biomass. Pedobiologia 49:127-137. doi:10.1016/j.pedobi.2004. 09.004

Gange AC, Brown VK (1989) Effects of root herbivory by an insect on a foliar-feeding species, mediated through changes in the host plant. Oecologia 81:38-42. doi:10.1007/BF00377007

Gange AC, Nice HE (1997) Performance of the thistle gall fly, Urophora cardui, in relation to host plant nitrogen and mycorrhizal colonization. New Phytol 137:335-343

Glenn SM, Collins SL, Gibson DJ (1992) Disturbances in tallgrass prairie: local and regional effects on community heterogeneity. Landsc Ecol 7:243-251. doi:10.1007/BF00131255

Gordon IJ, Illius AW (1994) The functional significance of the browser-grazer dichotomy in African ruminants. Oecologia 98:167-175. doi:10.1007/BF00341469

Haskell JP, Ritchie ME, Olff H (2002) Fractal geometry predicts varying body size scaling relationships for mammal and bird home ranges. Nature 418:527-530. doi:10.1038/nature00840 
Hopcraft JGC, Olff H, Sinclair ARE (2010) Herbivores, resources and risks: alternating regulation along primary environmental gradients in savannas. Trends Ecol Evol 25:119-128. doi: 10.1016/j.tree.2009.08.001

Jones CG, Lawton JH, Shachak M (1994) Organisms as ecosystem engineers. Oikos 69:373-386

Jones CG, Lawton JH, Shachak M (1997) Positive and negative effects of organisms as physical ecosystem engineers. Ecology 78:1946-1957. doi:10.1890/0012-9658

King TJ (1977) Plant ecology of ant hills in calcareous grasslands. 2. Succession on mounds. J Ecol 65:257-278

Klironomos JN (2002) Feedback with soil biota contributes to plant rarity and invasiveness in communities. Nature 417:67-70. doi: 10.1038/417067a

Kuijper DPJ, Bakker JP (2005) Top-down control of small herbivores on salt-marsh vegetation along a productivity gradient. Ecology 86:914-923. doi:10.1890/04-0693

Kuijper DPJ, Nijhoff DJ, Bakker JP (2004) Herbivory and competition slow down invasion of a tall grass along a productivity gradient. Oecologia 141:452-459. doi:10.1007/s00442-0041664-6

Kuijper DPJ, Beek P, van Wieren SE, Bakker JP (2008) Time-scale effects in the interaction between a large and a small herbivore. Basic Appl Ecol 9:126-134

Laca EA, Sokolow S, Galli JR, Cangiano CA (2010) Allometry and spatial scales of foraging in mammalian herbivores. Ecol Lett 13:311-320. doi:10.1111/j.1461-0248.2009.01423

Langbein J, Hutchings MR, Harris S, Stoate C, Tapper SC, Wray S (1999) Techniques for assessing the abundance of brown hares Lepus europaeus. Mammal Rev 29:93-116. doi:10.1046/j.13652907.1999.00040

Masters GJ (1995) The effect of herbivore density on host-plant mediated interactions between two insects. Ecol Res 10:125-133. doi:10.1007/BF02347934

Masters GJ, Brown VK (1992) Plant-mediated interactions between two spatially separated insects. Funct Ecol 6:175-179

McNaughton SJ (1984) Grazing lawns, animals in herds, plant form, and coevolution. Am Nat 124:863-886

Milchunas DG, Lauenroth WK (1993) Quantitative effects of grazing on vegetation and soils over a global range of environments. Ecol Monogr 63:327-366. doi:10.2307/2937150

Mortimer SR, van der Putten WH, Brown VK (1999) Insect and nematode herbivory below-ground: interactions and role in vegetation succession. In: Olff $\mathrm{H}$, Brown VK, Drent RH (eds) Herbivores: between plants and predators. Blackwell, Oxford, pp 205-238

Mouissie AM, Apol MEF, Heil GW, van Diggelen R (2008) Creation and preservation of vegetation patterns by grazing. Ecol Model 218:60-72. doi:10.1016/j.ecolmodel.2008.06.018

Olff H, Ritchie ME (1998) Effects of herbivores on grassland plant diversity. Trends Ecol Evol 13:261-265. doi:10.1016/S01695347(98)01364-0

Olff H, De Leeuw J, Bakker JP, Platerink RJ, van Wijnen HJ, De Munck W (1997) Vegetation succession and herbivory in a salt marsh: changes induced by sea level rise and silt deposition along an elevational gradient. J Ecol 85:799-814

Olff H, Vera FWM, Bokdam J, Bakker ES, Gleichman JM, de Maeyer K, Smit R (1999) Shifting mosaics in grazed woodlands driven by the alternation of plant facilitation and competition. Plant Biol 1:127-137. doi:10.1111/j.1438-8677.1999.tb00236

Olff H, Hoorens B, de Goede RGM, van der Putten WH, Gleichman JM (2000) Small-scale shifting mosaics of two dominant grassland species: the possible role of soil-borne pathogens. Oecologia 125:45-54. doi:10.1007/PL00008890

Olff H, Ritchie ME, Prins HHT (2002) Global environmental controls of diversity in large herbivores. Nature 415:901-904. doi: $10.1038 / 415901 \mathrm{a}$

Pontin AJ (1978) Numbers and distribution of subterranean aphids and their exploitation by ant Lasius flavus. Ecol Entomol 3:203-207

Ritchie ME, Olff H (1999) Spatial scaling laws yield a synthetic theory of biodiversity. Nature 400:557-560. doi:10.1038/23010

Sharrow SH (1984) A simple disc meter for measurement of pasture height and forage bulk. J Range Manag 37:94-95

Soler R, Bezemer TM, van der Putten WH, Vet LEM, Harvey JA (2005) Root herbivore effects on above-ground herbivore, parasitoid and hyperparasitoid performance via changes in plant quality. J Anim Ecol 74:1121-1130. doi:10.1111/j.1365-2656. 2005.01006.x

Soler R, Bezemer TM, Cortesero AM, van der Putten WH, Vet LEM, Harvey JA (2007) Impact of foliar herbivory on the development of a root-feeding insect and its parasitoid. Oecologia 152:257-264. doi:10.1007/s00442-006-0649-z

van der Heijden MGA, Klironomos JN, Ursic M, Moutoglis P, Streitwolf-Engel R, Boller T, Wiemken A, Sanders IR (1998) Mycorrhizal fungal diversity determines plant biodiversity, ecosystem variability and productivity. Nature 396:69-72. doi: $10.1038 / 23932$

van der Putten WH, Bardgett RD, de Ruiter PC, Hol WHG, Meyer KM, Bezemer TM, Bradford MA, Christensen S, Eppinga MB, Fukami T, Hemerik L, Molofsky J, Schadler M, Scherber C, Strauss SY, Vos M, Wardle DA (2009) Empirical and theoretical challenges in aboveground-belowground ecology. Oecologia 161:1-14. doi:10.1007/s00442-009-1351-8

van Ruijven J, De Deyn GB, Raaijmakers CE, Berendse F, van der Putten WH (2005) Interactions between spatially separated herbivores indirectly alter plant diversity. Ecol Lett 8:30-37. doi: 10.1111/j.1461-0248.2004.00688.x

Waloff N, Blackith RE (1962) The growth and distribution of the mounds of Lasius flavus (Fabricius) (Hym, Formiciade) in Silwood Park, Berkshire. J Anim Ecol 31:421-437

Wardle DA, Bardgett RD, Klironomos JN, Setälä H, van der Putten WH, Wall DH (2004) Ecological linkages between aboveground and belowground biota. Science 304:1629-1633. doi:10.1126/ science. 1094875 